Lise-Mari Lauritzen

UiT - Norges arktiske universitet

Yngve Antonsen

UiT - Norges arktiske universitet

Linda Nesby

UiT - Norges arktiske universitet

DOI: http://dx.doi.org/10.5617/adno.7848

\title{
«Jeg er så veldig redd for hvordan jeg påvirker elevene.» Utfordringer og muligheter i undervisningen av folkehelse og livsmestring i norskfaget
}

\begin{abstract}
Sammendrag
I den nye læreplanen (LK20) ble folkehelse og livsmestring innført som tverrfaglig tema i norsk skole. Denne studien undersøker begrepsforståelse, skjønnlitteraturens betydning og didaktikk knyttet til temaet. Våren 2019 ble 13 norsklærere fra fem videregående skoler intervjuet ved bruk av en semi-strukturert intervjuguide. Den tematiske analysen av datamaterialet viser følgende resultater: Lærerne formulerte utfordringer ved å skulle operasjonalisere begreper som mangler definisjon i de offentlige dokumentene. Samtidig ga lærerne uttrykk for at livsmestring allerede er en del av norskfaget. Lærerne pekte på at eksamensstyringen vektlegger de tekniske aspektene i norskundervisningen, noe som begrenser muligheten for tematisering. Lærerne anerkjente potensialet for at skjønnlitteraturen kunne brukes for å belyse folkehelse og livsmestring gjennom å veilede elevene mot å finne balansen mellom nærhet og distanse til teksten. Dette berører begrepet den skjønnsomme leseren (Nussbaum, 2016). Lærerne pekte på hvordan skjønnlitteratur kan oppleves som personlig relevant, historisk aktuell og fremme empatisk respons. Bruk av skjønnlitteratur åpner også for å undervise om vanskelige temaer uten å være for personlig, men dette krever pedagogisk intendert didaktikk. Lærerne uttrykte behovet for mer didaktisk kunnskap for å skape denne balansen, særlig i møte med sensitive temaer. I forståelsen og formidlingen av det tverrfaglige temaet folkehelse og livsmestring argumenter vi for at det er behov for å fremme og utvikle norskfagets egen diskurs og didaktikk. Studien er tilknyttet videregående opplæring, men vi mener den har overføringsverdi til alle skoleslag.
\end{abstract}

Nøkkelord: folkehelse og livsmestring, norsklærere, litteraturdidaktikk, skjønnlitteratur, norskfaget 


\title{
"I'm just so scared of how I'm affecting the students." Challenges and Possibilities of introducing Public Health and Life Mastery in the Norwegian Language Arts
}

\begin{abstract}
In the new curriculum for all school levels in Norway, the interdisciplinary topic public health and life mastery was introduced. This study investigates the understanding of the topic, the value of fiction and the didactics. In the spring of 2019, 13 Norwegian language arts teachers from five high schools were interviewed, with the use of a semistructured guide. Thematic analysis shows the difficulty of operationalizing concepts which lack clear definitions in the white papers. Meanwhile, the interviewed teachers stated life mastery as already existing in the subject and they addressed that the restrictive function of exams could confine the opportunities to thematize the topic. The teachers identified fiction as a tool to highlight life mastery through guiding the students towards finding a balance between closeness and distance while reading, a phenomenon that Nussbaum (1995) describes as the judicious spectator. The teachers suggested that fiction could be personally relevant, historically important and that it could promote empathetic responses. The use of fiction to teach difficult topics inspires conversations that are not private, but this demands pedagogical intention. The teachers expressed the need for more pedagogical and didactic knowledge on how to create this balance, especially concerning sensitive topics. We argue that there is a need to promote and develop the Norwegian language arts' own discourse and didactics in the understanding and dissemination of the interdisciplinary teaching of public health and life mastery. The study focuses on high school-level teaching, but we consider it relevant for all grades.
\end{abstract}

Keywords: public health and life mastery, teachers of Norwegian language arts, literature didactics, fiction, Norwegian language arts

\section{Innledning}

Innføringen av LK20 bygger på en omfattende fagfornyelse basert på Ludvigsenutvalgets vurderinger av samfunnets framtidige kompetansekrav (NOU, 2015). I fagfornyelsen skal demokrati og medborgerskap, bærekraftig utvikling og folkehelse og livsmestring innføres som tverrfaglige temaer i fagene der det er relevant. Folkehelse og livsmestring presenteres som omfangsrike begreper og målet er blant annet å gi elevene muligheten til å utvikle bevegelseskompetanse, kunnskap om kosthold, privatøkonomi og seksualitet samt å gi verktøy som kan hjelpe elevene til å ta gode livsvalg basert på kunnskap om fysisk og psykisk helse. Den overordnede delen av den nye læreplanen fastslår at innføringen av folkehelse og livsmestring innebærer å lære elevene å håndtere både positive og negative sider av livet (Kunnskapsdepartementet, 2017). Ifølge lærerplanen i norskfaget skal det tverrfaglige temaet omhandle utviklingen av skriftlige og muntlige ferdigheter i den hensikt å kunne uttrykke egne følelser og tanker. Videre skal skjønnlitteraturen bidra til å bekrefte og utfordre elevenes selvbilde. Beskrivelsen av 
folkehelse og livsmestring framgår kun i en egen del om de tverrfaglige temaene, og er ikke presentert i fagets kompetansemål (Kunnskapsdepartementet, 2019).

Innføringen av folkehelse og livsmestring samsvarer med at psykiske helseplager blant barn og ungdom i Norge har fått økt oppmerksomhet (Sletten \& Bakken, 2016). Verdens helseorganisasjon (WHO) presiserer at skolen er en arena for å utvikle et trygt sosialt og dannende miljø, som nettopp kan styrke elevenes prestasjoner og vurderingsevner om eget liv (Herrman et al., 2005). At nettopp skolen er pekt ut til å formidle kunnskap om komplekse sider ved livet, er ikke tilfeldig, og flere land i Europa har begynt å innføre helse i undervisningen (Weare \& Nind, 2011; Gabhainn et al., 2010).

Flere aktører har offentlig debattert innføringen av livsmestringsbegrepet i skolen (Mørch, 2020; Holtermann \& Vedvik, 2020). Madsen (2020), som er psykolog, er kritisk til at det er psykologene som hittil har ført den dominerende diskursen rundt hva livsmestring skal være, og på denne måten tolket det i retning av å dreie seg om elevenes psykiske helse og terapi. Lærerne har også ytret skepsis, for eksempel Tollefsen (2020). Han mener at livsmestring ser ut til å koples til personlige problemer som elevene selv skal ta ansvar for og ikke til livsutfordringer basert på politiske strukturer og samfunnets innretning. Weare og Nind (2011) viser med sin metastudie av internasjonal forskning at helsefremmende arbeid i skolen burde ta utgangspunkt i en helhetlig universell tilnærming og ikke undervises som et isolert tema gjennom informative strategier. Nyere forskning ved Hickey et al. (2019) trekker fram læreren som den viktigste aktøren for å undervise om helserelaterte temaer.

Skjønnlitteraturen er et alternativ til bruk av informative tekster. En rekke forskere har undersøkt forholdet mellom lesing av skjønnlitteratur og kognitiv utvikling. Hogan (2001) mener at litterære teknikker kan sette i gang empatiske prosesser hos leseren. Keen (2014) har videreutviklet disse tankene innenfor narrativ empati, en teori som tydeliggjør koplingen mellom fiksjon og empatisk respons. Også Kidd og Castano (2013) viser ved hjelp av empirisk forskning at lesing av skjønnlitteratur kan ha effekt på evnen til å sette seg inn i andres situasjon. I en norsk kontekst søker det tverrfaglige prosjektet Litteratur, kognisjon og emosjon, ledet av Karin Kukkonen (UiO), å forene humaniora og naturvitenskap i samtaler om skjønnlitteratur.

Norskfaget åpner for utvikling av språk og tanke, samtidig som elevene får innblikk i ulike kulturer og perspektiver (Penne, 2001; Aase, 2005; Fondevik \& Hamre, 2017). Når det kommer til empirisk forskning på skjønnlitteraturens betydning for utvikling, har Smidt (1989) vist at fiksjon skaper rom for å prøve ut ukjente situasjoner. Slike fiksjonelle handlingsrom kan bidra til utvikling og holdningsendring. Kjelen (2015) er opptatt av at undervisningen må legge opp til en balanse mellom fornuftsbasert og følelsesbasert tilnærming for at elevene skal ha effekt av lesingen. Lauritzen (2019a, 2019b) har bidratt med teoretiske perspektiver som påpeker at bruk av relevant skjønnlitteratur, samt kombinasjonen av innsikter og undervisningsmetoder fra litteraturvitenskap og narrativ medisin, 
kan gi grunnlag for å lære elevene om folkehelse og livsmestring. Jambak (2021) stiller seg også bak at skjønnlitteraturen kan være en nyttig verktøykasse for livsmestringsundervisningen. Goga (2019) har tematisert skjønnlitteraturens betydning for et av de andre tverrfaglige temaene, nemlig bærekraftig utvikling. Hun poengterer at det å lese oppmerksomt og deretter samtale om litteraturen kan utvikle kritiske perspektiver som kan gjøre elevene til bevisste økoborgere.

Det er behov for empirisk forskning på litteraturdidaktiske innganger til folkehelse og livsmestring. I denne artikkelen utforsker vi derfor følgende forskningsspørsmål: Hvilke muligheter og utfordringer ligger det $i$ å undervise i folkehelse og livsmestring i norskfaget på videregående skole? 13 norsklærere fordelt på fem skoler i Nordland og Troms ble intervjuet. I det følgende presenterer vi artikkelens teoretiske rammeverk, forankret i Martha Nussbaums tanker om bruk av skjønnlitteratur i undervisning. Deretter presenterer vi studiens utvalg, design, analyse og noen etiske betraktninger. Videre presenterer og drøfter vi resultatene. I konklusjonen oppsummerer vi studiens hovedfunn samt foreslår veier videre inn i forskningsfeltet.

Vi har hentet inspirasjon fra Nussbaum (1995, 2016) for å finne måter å operasjonalisere folkehelse og livsmestring på i norskundervisningen. Nussbaum mener at skjønnlitteraturen kan brukes i utdanningssystemet særlig med tanke på å utvikle demokratiske holdninger, medfølelse og empati blant elevene. I Poetic Justice (Nussbaum, 1995) argumenterer hun for at lærerne skal undervise i litteratur som påvirker og forstyrrer leserens verdensoppfatning. Et viktig poeng er at elevene skal utvikle seg til å bli judicious spectators i møte med litteraturen. Denne posisjonen handler om å kunne ta med egne erfaringer i lesingen, samtidig som leseren holder en kritisk avstand. Konkret handler det om å tilegne seg en filtreringsmetode. Dette er ikke ulikt den klassiske hermeneutiske tilnærmingen (Gadamer, 2012), der leseren tar med seg egen forforståelse inn i teksttolkningen, parallelt med at egne mål og framtidsprosjekter legges til side. På bakgrunn av dette mener Nussbaum (1995) at lesing av fiksjon kan øke sosial intelligens og empati.

Engelstad (i Nussbaum, 2016, s. 10) har oversatt the judicious spectator til den skjønnsomme leseren. For å bli en skjønnsom leser, argumenterer Nussbaum (2016) for at det er vesentlig å ha en forståelse av hva følelser er. Følelser oppstår ofte med utgangspunkt $i$ et objekt, og det sentrale er hvilke overbevisninger og vurderinger som knyttes til objektet. Nussbaum viser hvordan leseren må lære å skille mellom pålitelige og upålitelige følelser, samt å diskutere hva som er det riktige synet på kjensgjerningene i gitte situasjoner framstilt i skjønnlitterære verk. Dette gir grobunn for å se «at følelsene kan endres, når tankene forandres» (Nussbaum, 2016, s. 14). For at elevene skal ha en effekt av lesingen, er det viktig at de forstår sin egen sårbarhet, at de løfter blikket og erkjenner at livet er foranderlig.

Nussbaum har blitt kritisert for å være vag og for å basere seg på intuisjon heller enn fakta. Likevel får hun støtte fra nyere forskning, der blant annet 
nevropsykologene Duncan et al. (2017) argumenterer for at Nussbaums innsikter er veldokumentert i empirisk forskning. Nussbaums argumenter gir også resonans i moderne litteraturteori der blant annet Oatley (2016) viser hvordan skjønnlitteratur påvirker vår forståelse av verden og hvordan mennesker som leser mye skårer høyere på empati enn de som ikke leser skjønnlitteratur.

Per Thomas Andersen (2016) støtter Nussbaums argumenter fra et litteraturvitenskapelig ståsted. Andersen framhever hvordan unders økelser av karakterenes følelser kan gi leseren en forståelse av hvordan komplekse emosjonelle prosesser fungerer, noe som kan knyttes til folkehelse og livsmestring. I en eksplisitt norskfaglig kontekst argumenterer Andersen for at skjønnlitteraturen kan fungere som et verktøy for å lære seg å se verden fra ulike synsvinkler: «Hvis du ikke kan leve deg inn i hvordan andre har det, kan du verken være en god partner, en velfungerende forelder eller et gagnlig samfunnsmenneske» (Andersen, 2011, s. 19). Innlevelsesevnen er altså avgjørende for å kunne ha et velfungerende personlig og samfunnsmessig liv. Andersen beskriver fantasi- og innlevelsesevnen som en av de viktigste grunnleggende ferdighetene for framtiden, og norsklærere burde derfor søke å styrke denne ferdigheten hos elevene.

Kari Anne Rødnes (2014) viser med sin forskningsgjennomgang at bruk av elevenes egne erfaringer i undervisningen gjør det enklere for elevene å finne mening i tekstene, men samtidig er det nødvendig å åpne for analytiske tilnærminger til litteraturen som fremmer det faglige innholdet. Litteraturstudien til Rødnes viser at kunnskap om tekst og språk blir viktig for å finne denne balansen: «Elevene må hjelpes til å bevege seg konstruktivt mellom liv og tekst [...]» (Rødnes, 2014, s. 9). Dette kan skje gjennom en undersøkelse av forholdet mellom fiksjon og elevenes virkelighet, samt mellom fagspråk og elevenes hverdagsspråk (Kaspersen, 2004; Olin-Scheller, 2006).

Metode: utvalg, design og analyse

Denne studien tar utgangspunkt i et konstruktivistisk perspektiv der kunnskap produseres og forstås i dialog mellom mennesker (Crotty, 1998). Ni kvinnelige og fire mannlige norsklærere ble intervjuet, en kjønnsfordeling som også reflekteres i yrket. Deltakerne hadde ulik alder og undervisningserfaring, og det var ikke et krav at norsk måtte være et masterfag eller det faget de underviste mest i. Nesten alle lærerne underviste både på studieforberedende og på yrkesfaglige program. Studien ble utført våren 2019 ved lærernes arbeidssted og intervjuene varte 4090 minutter. Lærerne på en av skolene ble funnet ved hjelp av en universitetsskoleordning, mens de andre ble rekruttert ved at forespørsel om deltakelse ble spredt via bekjentskaper blant lærerne, altså snøballmetoden (Christoffersen \& Johannessen, 2012). Førsteforfatter kjente perifert til to av lærerne på forhånd. Samtlige lærere har gitt skriftlig informert samtykke til å delta, og studien er godkjent av NSD. 
I gjennomføringen av intervjuene ble det anvendt en semi-strukturert intervjuguide, og naturlig kommunikasjon ble vektlagt. Intervjuene ble innledet med to spørsmål:

- Hvor lenge har du arbeidet som lærer?

- Kan du fortelle litt om interesseområdene dine innenfor norskfaget?

Det ble spurt om interesseområder fordi det kan påvirke hvordan skjønnlitteraturen, som var et viktig holdepunkt i intervjuene, ble snakket om. Videre ble det spurt om fagfornyelsen:

- Hvordan jobber du og din skole med fagfornyelsen og folkehelse og livsmestring?

- Hvordan forstår du begrepene folkehelse og livsmestring?

Disse spørsmålene var essensielle for å kartlegge forkunnskaper; samtidig ga de en pekepinn på hvor forberedt lærerne var på å snakke om og undervise i temaet. Andre sentrale spørsmål i intervjuguiden var:

- Hva tenker du om å undervise om vanskelige temaer i norskfaget?

- Hvilke muligheter og utfordringer ser du med å undervise i folkehelse og livsmestring?

- Hvilken mening og kunnskap tenker du at skjønnlitteraturen kan gi med tanke på folkehelse og livsmestring, på både godt og vondt?

Det første spørsmålet ble fulgt opp med samtale om hva som anses som vanskelige eller tabubelagte temaer, noen fordeler og utfordringer ved undervisningen, undervisningserfaringer på området og hvorvidt lærerne hadde noen tanker knyttet til trygg undervisning. Sammenhengen mellom lesing, empati og didaktikk ble også berørt. Avslutningsvis ble det stilt to kontrollspørsmål:

- Kan skjønnlitteraturen bidra til å aktualisere folkehelse og livsmestring i norskfaget?

- Er norskfaget stedet for folkehelse og livsmestring?

De to siste spørsmålene er lukkede i den forstand at de styrer svarene i retning av ja eller nei. Lærerne ble imidlertid bedt om å begrunne svarene sine. Spørsmålene hadde som hensikt å være oppsummerende, samtidig som de kunne si noe om lærernes holdninger og forventninger.

En kvalitativ studie med 13 informanter har begrensninger relatert til overførbarhet og generalisering. Med tanke på studiens pålitelighet er det også viktig å påpeke at den kunnskap som genereres ut fra et intervju gjort $\mathrm{i}$ et konstruktivistisk perspektiv, har oppstått i det sosiale møtet mellom forsker og informant. Bruk av åpne spørsmål i intervjuguiden ga informantene mulighet til å snakke om temaer som var viktige for dem, og lukkede spørsmål skulle fungere som kontrollspørsmål. Denne fleksible formen for intervju ga rom for å innhente data 
som vi ikke på forhånd visste var av interesse. Intervjuer ønsket å legge til rette for en intervjusituasjon som ikke fokuserte på faktakunnskap om litteratur eller undervisning, og lærerne var ikke kjent med det teoretiske rammeverket som presenteres i denne artikkelen. Intervjuene ble tatt opp ved hjelp av båndopptaker og senere transkribert ortografisk, der meningsskapende elementer som lydord, pauser, nøling og latter også ble tatt med (Kvale, 2007).

Intervjusituasjonen ble vurdert med utgangspunkt i Järvinens fire analytiske punkter (Järvinen \& Mik-Meyer, 2005). Det første handler om sosial identitet, strategi og inntrykksstyring. En illustrerende situasjon var da en lærer hadde lest informasjonsskrivet grundig og trakk fram punkter som vedkommende særlig ønsket å diskutere uavhengig av intervjuguiden. Det andre punktet dreier seg om å gå i dybden på informantenes narrativer. Lærerne ga uttrykk for at skolen samlet ikke hadde jobbet mye med fagfornyelsen. De ga også uttrykk for å være under et daglig arbeidspress som gjorde det utfordrende å sette seg grundig inn i nye temaer. De to siste analysepunktene handler om å forstå hvordan mening skapes og at datamaterialet er komplekst og formet av intervjuets prosjekt. Blant annet inneholdt informasjonsskrivet som lærerne fikk i forkant av intervjuet, en beskrivelse av doktorgradsavhandlingen som intervjustudien er en del av. Hensikten var å møte lærerne med transparens. I informasjonsskrivet kom det fram at folkehelse og livsmestring hadde blitt knyttet opp mot psykisk helse, noe som kan ha påvirket lærernes forforståelse og følelser knyttet til begrepene. Intervjuer hadde likevel inntrykk av at lærerne viste integritet og oppriktighet.

Dataprogrammet NVivo12 ble brukt for å analysere datamaterialet, og det ble tatt utgangspunkt i en tematisk tilnærming basert på Braun og Clarke (2012). Førsteforfatter startet med å høre gjennom lydopptakene, transkribere dem og å lage refleksjonsnotater. Deretter kodet hun materialet i kontinuerlig dialog med medforfatterne. Det ble i alt 21 koder, der begrepsforståelse, erfaring, holdning til lareplanen, lcerernes bakgrunn, skjønnlitteratur og utfordringer var blant de mest brukte. Med utgangspunkt i kodene ble ulike tematiske kart tegnet opp for å identifisere og diskutere likheter og ulikheter. I løpet av dette steget ble forskningsspørsmålene videreutviklet og spesifisert.

Lærerne viste en større interesse for livsmestring enn for folkehelse. Dette kan handle om at intervjuer viste mer interesse for livsmestringsbegrepet, da det er nyere og mer komplekst. I analysen ble det avdekket fire hovedtemaer: livsmestring - allerede en del av norskfaget, eksamensstyringen i norskfaget, skjønnlitteratur og livsmestring samt utfordringer og muligheter $i$ undervisningen. I fortsettelsen presenterer vi disse og diskuterer dem opp mot det teoretiske rammeverket. Lærerne refereres til som L1-L13. 


\section{Resultater og diskusjon}

\section{Livsmestring - allerede en del av norskfaget?}

Lærerne hadde utfordringer med å definere folkehelse og livsmestring. Det er på mange måter forståelig da de befant seg i en muntlig intervjusituasjon der de ikke hadde blitt bedt om å forberede seg på forhånd. Lærerne uttrykte frustrasjon over de vide begrepene. Det var imidlertid en felles oppfatning at folkehelse var noe som kunne knyttes til det kollektive og fysiske, mens livsmestring var mer individuelt og psykisk. Lærernes forståelse av livsmestring beveget seg raskt mot aspekter knyttet til det å ikke mestre livet. Flere lærere kom inn på at det er de elevene som har det vanskelig, som må være målgruppen for innføringen. Denne tanken suppleres med en bekymring fra L13: «Det er jo den der redselen for at vi lærere nå skal være hobby-psykologer.» Denne bekymringen ble delt av til sammen seks lærere. Det ble også fremmet en tanke om at hvis livsmestringsundervisningen skal rettes mot de elevene som allerede har problemer, vil dette føre til at norskfaget ikke bare mister sin faglighet, men også sitt danningsprosjekt, siden danning krever faglig kompetanse.

Det siste oppsummerende kontrollspørsmålet i intervjuguiden viste at flere hadde en oppfatning om at livsmestring alltid hadde vært en indirekte del av faget gjennom både litteraturdidaktikken og danningsaspektet. L13 kom med noen konkrete eksempler: «Hvis en drar livsmestring til at det handler om å kunne formulere seg, å skrive og lese godt, så er jo det kjerneområdet til norskfaget allerede.» L1 påpekte også spesifikt litteraturens og litteraturdidaktikkens betydning: «Men livsmestring har vi jo jobbet med igjennom litteraturen, spesielt i realistiske tradisjoner, med livsmestring og å leve på en løgn og ja, alt sånt som litteraturen kan [ler]», mens L2 var noe mer forsiktig i sin framstilling: «Jeg tror vi, altså, vi roter oss nå bort i det [livsmestring] på et vis [pause], når vi snakker om tekst.» Her utrykte L2 en usikkerhet som kan knyttes til uklar begrepsforståelse. $\AA$ «rote bort i» kan vise til å uintendert berøre temaet i undervisningen. L10 så livsmestring i en større sammenheng, og beskrev det nærmest metaforisk: «Det er jo hele skolegangen som danner grunnlaget for livsmestring.» På bakgrunn av det som kom fram i intervjuene konkluderte flertallet med at norskfaget var et naturlig sted for livsmestring. Det kan se ut til lærerne gjennom fagfornyelsen har blitt mer bevisste og fătt et utvidet vokabular som gjør at de knytter livsmestringstemaet til norskundervisningen.

Til tross for at livsmestring ble sett på som noe som alltid hadde eksistert i faget, var flere skeptiske til å gjøre det eksplisitt for elevene. Dette kan være knyttet til usikker begrepsforståelse, men det kan også handle om det som har kommet fram i den offentlige debatten om at det å innføre et slikt begrep kan skape et inntrykk av at livsmestring er noe som gjøres i større eller mindre grad, og at mestringen er målbar. Samtidig kan skjønnlitteraturen med sin evne til å vise komplekse livsverdener og sammensatte karakterer demme opp for forestillingen av livsmestring som en målbar størrelse. 


\section{Eksamensstyringen i norskfaget}

Opprinnelig var det ikke spesifikke spørsmål i intervjuguiden knyttet til eksamen, men dette ble uoppfordret snakket om av sju lærere. I disse samtalene kom det fram at skolens stramme eksamensfokus er problematisk både for norskfagets mulighet til å danne elevene, for å skape engasjement for lesing og skriving, og videre for at norskfaget skal ha en større betydning for liv og samfunn. En slik problematikk er velkjent i skolen (Aase, 2005; Dysthe \& Webler, 2010; Stølen, 2017). Lærerne så det som utfordrende å skulle integrere overordnede, tverrfaglige temaer når eksamen styrer slik den gjør. L5 uttrykte at eksamen gjør norskfaget teknisk:

Det er utrolig lite som går på, ehm, innholds- denne [pause], skulle jeg si, dannelsesbiten, sant. Det får i liten grad plass i vurderingen, og det er det tekniske som er veldig, veldig tungt vektet.

L5 kom ikke med konkrete eksempler som beskrev det tekniske, men videre ble dette satt opp mot det at elevene ikke får spekulere eller teste ut ting samt uttrykke seg gjennom kreativ skriving på eksamen. Ifølge henne er de såkalte kreative eksamensoppgavene i realiteten så styrt at det ikke handler om å være kreativ, men å holde seg innenfor en fastlåst ramme. En annen lærer (L6) fulgte opp med å si: «På eksamen burde du aldri skrive kreativ tekst, for da stryker du.» Dette har betydning for verdien av kreative og skjønnlitterære tekster. L5 og L6 mente begge at eksamenspresset gjør det vanskelig å fokusere på temaer som kunne vært nyttige i sammenheng med livsmestring: «Hvis litteraturen skal ha en funksjon, så er det jo det du skal se på, ikke egentlig hvor godt det stemmer inn i [pause], en litterær periode. (L5)» L6 fulgte opp med å mene at eksamensformen ødelegger for skjønnlitteraturens potensial i faget, og at eksamen gjør litteraturen til et objekt for teknisk analyse og til noe som skjematisk skal plasseres i en litteraturhistorisk sammenheng. Den mister betydningen den kunne hatt for elevenes utvikling og engasjement. En annen lærer (L7) hadde likevel tro på at skjønnlitteraturen og litteraturdidaktikken uansett evner å påvirke elevene, fordi litteraturen gir så unike tilganger til menneskesinnet. Flere av lærerne trakk fram at det er bedre å være lærer på Vg2 enn på Vg3, for da kan de ta seg tid til å diskutere og oppleve faget på en annen måte, nettopp fordi utsiktene til eksamen ikke styrer i like stor grad.

Tveit og Olsen (2018) mener at det er uavklart hva som skal være målet med eksamen, og de foreslår at eksamenssystemet burde gjennomgås slik at dette tydeliggjøres. Funnene fra studien vår støtter denne oppfordringen. Lærerne opplevde at forholdet mellom eksamen og de tverrfaglige temaene var uklart, noe som kan forstyrre implementeringen av folkehelse og livsmestring i norskfaget. Et annet funn indikerer at skjønnlitteraturen heller ikke kommer til å anvendes konkret i implementeringen, men at mer tekniske og analytiske sider av lesingen som lettere lar seg underkaste ulike vurderingsformer, blir vektlagt. Dette samsvarer med funn fra Gabrielsen et al. (2019). 


\section{Skjønnlitteratur og livsmestring}

Lærerne var enige om at skjønnlitteraturen kan vise elevene ulike former for livsmestring, livskvalitet og forskjeller. L10 var inne på at livsmestring kunne handle om problemløsing, noe skjønnlitteratur kunne bidra til å belyse bedre enn sakprosa:

En fagtekst eksisterer her og nå, okei, spiseforstyrrelser, jo det er det og det, og hvis man ikke får satt struktur og kjøtt og bein på det der, så er det bare ei faktaopplysning, men hvis man derimot kan knytte det opp mot en skjønnlitterær tekst der faktiske folk enten opplever eller ser andre oppleve, ja, for eksempel spiseforstyrrelser, så kan det få en litt mer langvarig virkning faktisk. Det gir rom for ettertanke.

Tanken om at skjønnlitteraturen er mer kompleks og har et større meningspotensial enn sakprosa, støttes av forskningen (Weare \& Nind, 2011; Duncan et al., 2017). L7 var også opptatt av dette. Hun koplet sammen psykologifaget og norskfaget, og hevdet i likhet med L10 at skjønnlitteraturen og litteraturdidaktikken har et særlig bidrag fordi de «kan tilføre mye, mye mer enn bare de faglige begrepene. Du går jo inn i karakterer, hvordan takler de hendelser, hvordan forstår de verden» (L7). L6 supplerte med å fastslå at vi gjennom skjønnlitteraturen kan unngå at livsmestring blir til noe terapeutisk.

Lærerne fikk også spørsmål knyttet til sammenhengen mellom skjønnlitteratur og empati, her forstått som evnen til å sette seg inn i andres situasjon. Årsaken til at intervjuer spurte om dette, var at hun selv hadde reflektert over koplingen mellom empati og livsmestring i tidligere arbeid (Lauritzen, 2019b). Selv om ikke alle lærerne intuitivt foretok en kopling mellom empati og litteratur, var de positive. L13 kom med en rekke eksemplifiseringer:

Jeg tror det er et stort potensial der, både med bevegelse i tid og å få empati for hvordan mennesker har hatt det før, sammenlignet med hvordan vi har det nå. Litteraturen har potensial til å fortelle personlige historier, som jeg tenker kan utvikle empati, for vi kan jo også høre veldig mye om hvordan folk har det i andre deler av verden, tall og statistikk, men det går ofte ikke sånn innpå, som når du hører personlige framstillinger av hvordan ting er.

Her berører L13 skjønnlitteraturens evne til å gi kunnskap om mennesket som vi ikke kan hente fra andre steder. Hun snakker også om utviklingen av innlevelsesevnen, som Andersen (2011) beskriver som en viktig grunnleggende ferdighet. Dette handler om muligheten for at litterære tekster kan være en kilde for å granske ulike følelser, både sårbarhet, styrke og forventninger, men også uforutsigbarhet. L9 var imidlertid usikker på om lesing øker empatien hos lesere som er empatiske i utgangspunktet, eller om lesingen faktisk gjør oss empatiske. L11 reflekterte over hvorvidt elevene trenger riktig veiledning for at skjønnlitteraturen skal kunne ha en positiv effekt, og viste til et historisk perspektiv: «Det var jo de mest dannede skjønnånder som gjorde de grusomste ting, i Hitler-Tyskland, ikke sant, det vet vi jo.» Her berøres negative sider ved kunsten som viser at innsikten tilegnet gjennom litteraturen ikke nødvendigvis er positivt dannende. 
L4 var opptatt av at litteratur kan utfordre elevene og gi dem nye perspektiver: «Jeg tenker at det er veldig greit at de kommer ut av bobla si, at de ser at det skjer andre ting rundt seg.» L4 fortalte at hun i julen bevisst valgte å presentere tekster for elevene sine som hun håpet ville skape refleksjoner over hvordan andre har det. Her brukte hun blant annet «Karens jul» av Amalie Skram og «Piken med svovelstikkene» av H. C. Andersen. Hun mente at de fleste elevene lot seg berøre av tekstene, til tross for at de hadde få umiddelbare berøringspunkter med elevenes egen hverdag. Lærernes utsagn om bruk av litteratur faller sammen med Nussbaum (2016) og Andersen (2011) sine argumenter knyttet til å velge litteratur som forstyrrer elevene for å berøre og utvikle innlevelsesevnen deres.

\section{Utfordringer og muligheter $\mathrm{i}$ undervisningen}

Særlig to spørsmål i intervjuguiden satte i gang didaktiske refleksjoner. Det ene spørsmålet gikk på generelle muligheter og utfordringer i undervisningen om folkehelse og livsmestring og var ikke direkte koplet opp mot skjønnlitteraturen. Svarene tenderte mot et fokus på utfordringer heller enn muligheter. Det andre spørsmålet handlet om skjønnlitteraturens potensial, og her var svarene mer nyanserte og preget av en mer søkende holdning.

Lærerne var kritiske til innføringen av folkehelse og livsmestring, og en av lærerne (L10) fortalte at han først og fremst var usikker på om livsmestring kunne læres bort:

Vi kan alltids åpne opp kunnskap for dem, men det er jo de som må ta den til seg og det er jo de som må internalisere det og kanskje prøve å anvende det. [...] Eller som det heter, du kan lede hesten frem til vannet, men du kan ikke tvinge ham til å drikke.

L10 mener at livsmestring kan bety så mye, og at det er noe som varierer fra person til person. Det kan også være vanskelig å avgjøre hva som er god livsmestring. Dette handler også om å arbeide mot at elevene skal innta en aktiv rolle i lesingen, der de lærer å navigere i teksten, være kritiske og å gjøre seg opp egne meninger.

Skjønnlitteraturens evne til å berøre leseren står i datamaterialet fram som et usikkert element. På den ene siden vil lærerne at elevene skal bli berørte og litt forstyrret av litteraturen, i tråd med Nussbaums (1995) argumenter. Samtidig bekymrer lærerne seg for hvordan de vanskelige temaene i litteraturen kan påvirke elevene. Flere lærere rapporterte at de hadde hatt elever som åpent delte problemene sine i klasserommet, både i sammenheng med litterære samtaler og i uformelle situasjoner. Lærer L11 bemerket utfordringene:

Det er egentlig litt påtakelig at det er de som har utfordringer selv som vil gå dypere inn i det, [...] de leser litteraturen med mer sånn beskrivende [pause], de leser den ikke som litteratur.

L11 illustrerer hvordan elevene kan ha lav terskel for å formidle private problemer, noe som for øvrig er i tråd med framveksten av den moderne delingskulturen og sosiale medier. Da lærerne ble oppfordret til å snakke om hvorvidt de 
var skolert for å undervise om vanskelige temaer, kom det fram at verken de erfarne eller de nyutdannede lærerne følte seg kvalifiserte. Flere etterlyste at scenarier der elevene delte svært private ting ble tematisert i lærerutdanningen. Lærerne som valgte å trekke inn egen litteraturfaglig utdanning, fortalte at de naturligvis hadde studert tekster som berørte vanskelige og tabubelagte temaer. Det var imidlertid ikke gitt et pedagogisk fokus på bruken av slike potensielt krevende tekster i undervisningen. Utdanningen hadde heller ikke gitt redskaper for å utvikle elevene til å bli skjønnsomme lesere.

Selvmord er et eksempel på et vanskelig og tabubelagt tema, som kan tolkes som å være et resultat av manglende livsmestring. Lærerne ble spurt om hvilke tanker de hadde rundt tematisering av dette i norskundervisningen. Flertallet opplyste at de ikke ønsket å berøre det eksplisitt. Noen foreslo imidlertid en indirekte innfallsvinkel der klassen leste litteratur som perifert nevnte det, og særlig anvendelig i så måte var eldre, gjerne kanonisert litteratur. Det ble framhevet at det kunne være en større risiko for at elevene identifiserte seg med det litterære innholdet i samtidslitteraturen enn i den kanonisert litteraturen. Her ble Ibsens Vildanden (1884) brukt som eksempel. Dette kom av den tidsmessige distansen mellom elevenes sanntid og tekstenes fiksjonstid. Argumentet kan settes i sammenheng med å gjøre elevene til skjønnsomme lesere, der den kanoniserte litteraturen er et uttrykk for en metode for å skape distanse. Likevel, også ved bruk av klassiske tekster var lærerne tilbakeholdne med å tematisere selvmord. I forbindelse med Vildanden trakk flere fram at det var så mye annet enn selvmordet til Hedvig de heller ville snakke om. En nevnt utfordring var imidlertid at noen elever mener at de gamle tekstene er lite relevante for dem. Smidt (1989) påpeker at en ulempe med arbeidet for å skape en distanse til litteraturen, er nettopp at det kan føre til at elevene utvikler holdninger om at lesing og litteratur er kjedelig.

Frykten for smitteeffekt ved omtale av selvmord synes også å ligge til grunn for behovet for å skape en distanse til litteraturen. Dette speiler den samme varsomheten som finnes i media når det gjelder selvmord. På spørsmål om litteraturen kunne være skadelig, ble smitteeffekten eksplisitt nevnt. L8 la det fram på denne måten: «Jeg er så veldig redd for hvordan jeg påvirker elevene, hvis jeg begynner å snakke om det [spiseforstyrrelser/selvmord].» Lærerne var likevel enige om at vanskelige temaer, slike som selvmord eller spiseforstyrrelser, ikke burde ties om: «[Pause] Man skal ikke være redd for tabubelagte temaer, det er nå en del av livet og det er jo en del av litteraturen.» (L7) Det som er utfordrende er derimot å finne ut av hvordan det skal tematiseres på en trygg måte. Tre lærere nevnte også en annen utfordring, at skjønnlitteraturen kan gjøre leserne fordomsfulle, særlig om det er snakk om dårlig litteratur med flate karakterer. På denne måten kan elevene utvikle stereotype oppfatninger.

Selv om at lærerne så flere potensielle problemer, så de også mulighetene knyttet til implementeringen av folkehelse og livsmestring. L6 var tydelig på at skjønnlitteraturens potensial nettopp består i å lese tekster som berører personlige temaer uten at elevene selv trenger å dele privat informasjon: 
Jeg tror at hvis du tar utgangspunkt i et litterært verk så åpner det for at vi kan diskutere noe som ligger utenfor dem selv, så kan de ta inn sine egne erfaringer i den diskusjonen da, men det åpner for at vi kan diskutere temaet på basis av det litterære før vi tar oss selv.

L6 uttrykker betydningen av å finne en balanse mellom distanse og nærhet til teksten, fordi det åpner for at elevene kan bruke seg selv i lesingen. L7 hadde også stor tro på dette: «[...] man [trenger] jo ikke å være kjempepersonlig heller, altså man diskuterer ut fra noe som er litt trygt, fordi dette er en tekst.» Denne tanken støttes av blant annet Rødnes (2014) og Kjelen (2015).

Lærerne uttrykte at det var viktig å kjenne elevene sine godt i forbindelse med gjennomgangen av vanskelige temaer. Lærerne framhevet betydningen av forberedelser og tiltak for å advare de elevene som kunne ha et nært forhold til temaet. Å kunne snakke om litteratur på en måte som er trygg for alle, er et viktig bidrag fra norskfaget. Kanskje er dette kjernen i fagets rolle i den tverrfaglige formidlingen av et tema der sjansen er stor for å berøre alvorlige utfordringer i livet. Det kommer fram i materialet at skjønnlitteraturen også har fordeler her fordi læreren kan sette disse temaene inn i særlige kontekster. Ved å skape kunnskap om språk og tekst, altså gjennom en norskfaglig terminologi, slik som Kaspersen (2004) og Olin-Scheller (2006) beskriver, kan det utvikles et læringsmiljø der alle elevene på lik linje kan være med i undervisningen uavhengig av personlige erfaringer. Likevel viser forskningen at det nettopp må være plass til elevenes egne erfaringer i lesingen (Rødnes, 2014; Kjelen, 2015; Nussbaum, 2016). Grensen for det som er naturlig for elevene å dele i klasserommet kan være hårfin, og i implementeringen av folkehelse og livsmestring er det allerede kartlagt utfordringer knyttet til at elevene føler seg presset til å dele ting med klassen (Holtermann \& Vedvik, 2020). Å finne en passende balanse krever god kjennskap til elevene og klassedynamikken, samt faglig integritet og modenhet hos lærerne. Et problem er imidlertid at mye av forskningslitteraturen som drøfter livsmestring som et generelt tema i skolen, har et terapeutisk perspektiv (Sælebakke, 2018; Ringereide \& Thorkildsen, 2019). Det samme gjelder formuleringen i fagplanen om at litteraturen skal bekrefte og utfordre elevens selvbilde. Selvbilde handler om hvordan vi oppfatter oss selv, hvordan vi tror vi oppfattes av andre og hvordan vi ønsker å være. Dette kan skape et etisk dilemma for lærerne som dreier seg om hvem som eventuelt skal ha rett til å bekrefte eller utfordre et selvbilde. Det er en utfordring at både livsmestring og selvbilde er begreper som intuitivt ligger nærmere utviklingspsykologien enn pedagogikken, som norskfaget har å bidra med. Dette understreker følelsen av manglende faglig kompetanse som flere av lærerne rapporterer om i møte med livsmestringsperspektivet.

Til tross for at noen elever mener at lesing og litteratur er kjedelig, løftet flere lærere fram at det kan se ut til at det er de utfordrende temaene i litteraturen som engasjerer. De begrunnet dette med at psykisk helse, nærmere bestemt psykisk sykdom, var et tema som gikk igjen i elevenes fordypningsoppgaver. Bakgrunnen for interessen var ikke direkte gjenstand for refleksjon, men den kan være knyttet 
til den økende oppmerksomheten og populariteten som biografier og skjønnlitteratur om psykisk sykdom har fått de siste årene. I sin lærebok for danskfaget, Galskab i litteraturen, mener Gammelgaard og Boström at forklaringen på den økende interessen for slik litteratur kan være at den utgis «som en reaktion på eller konsekvens af det, man har kaldt præstationssamfunnet, hvor der stilles krav, som det kan synes umuligt at leve op til» (2019, s. 10). Dette kan være noe elevene kjenner seg igjen i og vil utforske. Vi kan også se det i sammenheng med argumentene til Nussbaum (2016) og Andersen (2016). Bondevik et al. (2017, s. 11) stiller imidlertid spørsmål ved om den økte oppmerksomheten rundt helse og sykdom egentlig fører til opplysning og nyttig kunnskap, eller om den bidrar til sykeliggjøring og angst. Disse bekymringene er ikke direkte rettet mot bruk av skjønnlitteratur i undervisning, men de er likevel relevante for litteraturdidaktikken og innføringen av folkehelse og livsmestring i norskfaget.

\section{Konklusjon}

Denne artikkelen utforsker hvilke utfordringer og muligheter som ligger i det å undervise i folkehelse og livsmestring for norsklærerne i videregående skole. Våre resultater viser at norsklærerne mente at det tverrfaglige temaet er vanskelig å forstå. Dette kan ha sammenheng med at intensjonserklæringen og implementeringsstrategien fra departementet i forbindelse med innføringen framstod som uklare på intervjutidspunktet. At kjernebegrepet livsmestring vanskelig lar seg definere, er en utfordring for bruken av begrepet i undervisningen: det er åpenbart vanskelig å operasjonalisere noe som framstår som utydelig.

Våre funn viser at norsklærerne opplevde eksamensstyringen som en utfordring med tanke på implementeringen av folkehelse og livsmestring. Eksamen gjør faget og lesingen av fiksjon teknisk, og det blir mindre rom for kreativitet og undring. En utfordring blir derfor at eksamensstyringen begrenser handlingsrommet lærerne har for å formidle det tverrfaglige temaet.

Lærerne framhevet at skjønnlitteraturen og norskfagets øvrige danningsaspekt har bidratt til at livsmestring alltid har vært en del av norskfaget. Dette kan fungere som en inngang til å gjøre livsmestring eksplisitt i undervisningen, men det kan også bli en hvilepute og dermed ikke endre eksisterende praksis. Lærerne samlet seg likevel rundt synet på skjønnlitteratur som et redskap for å nærme seg komplekse problemstillinger knyttet til folkehelse og livsmestring.

For at elevene skal få utbytte av litteraturlesingen, må fokuset ligge på god pedagogikk og didaktikk slik at litteraturen ikke bidrar til å skape stereotypier. Tidligere forskning (Sælebakke, 2018; Ringereide \& Thorkildsen, 2019; Madsen, 2020) viser at det er psykologien som har etablert den ledende diskursen knyttet til forståelsen av livsmestring. Dette er utfordrende, da det kan føre undervisningen i retning av å bli terapeutisk, noe som ligger utenfor norsklærernes mandat og faglige kompetanse. Våre funn viser imidlertid at norskfagets egen didaktikk 
og terminologi, og norsklæreren med sin litterære kompetanse, kan bidra i formidlingen av det tverrfaglige temaet. Ved å skape en trygg tilnærming gjennom litteraturen, kan elevene på avstand betrakte hva livsmestring eventuelt kan være og på den måten fastholde begrepets kompleksitet og diversitet som noe positivt, samt betone at det ikke dreier seg om en form for selvregulering med tanke på hvordan livet skal eller bør mestres. Denne artikkelen bidrar til forskningen på folkehelse og livsmestring i skolen ved å ta til orde for at fagene må finne fram til sine særegne bidrag til den tverrfaglige formidlingen.

Forskningsfeltet som omhandler fagfornyelsen og de tverrfaglige temaene er naturligvis nytt, og derfor er mer forskning nødvendig. Funnene i studien vår indikerer at lærerne trenger mer didaktisk kunnskap for å skape balanse mellom distanse og nærhet til litteraturen, særlig i møte med sensitive temaer. Rødnes (2014, s. 7) påpeker: «Den forskningen som er presentert, viser imidlertid også at mange av forskerne ser behovet for mer systematisk opplæring knyttet til det litterære arbeidet.» Våre funn samsvarer med dette. Denne studien er tilknyttet videregående opplæring, men vi mener den har overføringsverdi til hele skoleløpet.

I framtiden ser vi behovet for å gå tilbake til skolen for å undersøke hvordan implementeringen av folkehelse og livsmestring praktiseres. Vi foreslår at framtidig forskning blant annet tar for seg livsmestringsundervisningen i et elevperspektiv og identifisering av konkrete undervisningsmetoder ved hjelp av aksjonsforskning. Vi vil også påpeke behovet for forskning på hvordan temaets tverrfaglighet konkret kan operasjonaliseres, og ikke minst for drøfting av vurderingen knyttet til temaet. Det kan være vanskelig nok for unge mennesker å snakke om temaer som grenser inn mot det personlige, om de ikke også vet at de vurderes. Det vi allerede kan slå fast er at vurderingen bør gjennomføres på en måte som er tydelig på å teste faglig kunnskap.

\section{Takk}

Vi ønsker å takke lærerne i studien for åpenhet og generøsitet med hensyn til å drøfte et tema som for de fleste fortsatt var uavklart og i prosess. Vi takker også fagfellene og redaktør for konstruktive og fruktbare innspill som har bidratt til å løfte og styrke artikkelen. 


\section{Forfatterbidrag}

Alle forfatterne har bidratt til artikkelen i henhold til Vancouver-reglene. Artikkelen er gjennomlest og godkjent av alle. Særlige bidrag fra forfatterne:

LML (førsteforfatter):

Design, datainnsamling, teori, analyse, manus og revidering.

YA (andreforfatter) og LN (tredjeforfatter):

Innspill på datainnsamling, innledende analyse, kritisk gjennomlesing, kommentarer og innspill til revidering.

\section{Om forfatterne}

Lise-Mari Lauritzen er stipendiat i pedagogikk/norskdidaktikk. Hennes forskningsinteresser omfatter implementeringen av folkehelse og livsmestring i videregående skole, litteraturdidaktikk og Medical Humanities.

Institusjonstilknytning: Institutt for lærerutdanning og pedagogikk, UiT - Norges arktiske universitet, Postboks 6050 Langnes, 9037 Tromsø.

E-post: lise-mari.lauritzen@uit.no

Yngve Antonsen er førsteamanuensis i pedagogikk. Hans forskningsinteresser omfatter ledelse, endring og læring i organisasjoner. Han leder RELEMASTprosjektet som følger lærere med masterutdanning i deres første fem år i yrket. Institusjonstilknytning: Institutt for lærerutdanning og pedagogikk, UiT - Norges arktiske universitet, Postboks 6050 Langnes, 9037 Tromsø.

E-post: yngve.antonsen@uit.no

Linda Nesby er førsteamanuensis i nordisk litteratur. Hennes forskningsinteresser omfatter selvbiografiske sykdomshistorier, sykdomsskildringer i skandinavisk samtidslitteratur og celebritetsstudier og helse. Hun er leder for den tverrfaglige forskningsgruppen Health, Art and Society (HAS) ved UiT.

Institusjonstilknytning: Institutt for språk og kultur, UiT - Norges arktiske universitet, Postboks 6050 Langnes, 9037 Tromsø.

E-post: linda.nesby@uit.no 


\section{Referanser}

Andersen, P. T. (2011). Hva skal vi med skjønnlitteratur i skolen? Norsklæraren, 2(11), 15-22. https://docplayer.me/383073-Hva-skal-vi-med-skjonnlitteraturen-i-skolen.html

Andersen, P. T. (2016). Fortelling og følelse - En studie i affektiv narratologi. Universitetsforlaget.

Bondevik, H., Madsen, O. J. \& Solbrække, K. N. (2017). Snart er vi alle pasienter Medikalisering i Norden. Spartacus forlag AS / Scandinavian Academic Press.

Braun, V. \& Clarke, V. (2006). Using thematic analysis in psychology. Qualitative Research in Psychology, 3(2), 77-101. https://doi.org/10.1191/1478088706qp063oa

Christoffersen, L. \& Johannessen, A. (2012). Forskningsmetode for læererutdanningene. Abstrakt forlag.

Crotty, M. (1998). The Foundations of Social Research: Meaning and Perspective in the Research Process. SAGE.

Duncan, C., Bess-Montgomery, G. \& Osinubi, V. (2017). Why Martha Nussbaum is Right: The Empirical Case for the Value of Reading and Teaching Fiction. Interdisciplinary Literary Studies, 19(2), 242-259. https://doi.org/10.5325/intelitestud.19.2.0242

Dysthe, O. \& Webler, W.-D. (2010). Pedagogical issues from Humboldt to Bologna: The Case of Norway and Germany. Higher Education Policy, 23(2), 247-270. https://doi.org/10.1057/hep.2010.9

Fondevik, B. \& Hamre, P. (2017). Norsk som reiskaps- og danningsfag. Samlaget.

Gabhainn, S. N., O’Higgins, S. \& Barry, M. (2010). The implementation of social, personal and health education in Irish schools. Health Education, 110(6), 452-470. https://doi.org/10.1108/09654281011087260

Gabrielsen, I. L., Blikstad-Balas, M. \& Tengberg, M. (2019). The role of literature in the classroom: How and for what purposes do teachers in lower secondary school use literary texts? L1 - Educational Studies in Language and Literature, 19, 1-32. https://doi.org/10.17239/L1ESLL-2019.19.01.13

Gadamer, H.-G. (2012). Sannhet og metode: Grunntrekk i en filosofisk hermeneutikk. Pax. Gammelgaard, L. \& Boström, T. S. (2019). Galskab i litteraturen. Systime.

Goga, N. (2019). Økokritiske litteratursamtaler - en arena for økt bevissthet om økologisk samspill? Acta Didactica Norge, 13(2), Art. 3. https://doi.org/10.5617/adno.6447

Herrman, H., Saxena, S. \& Moodie, R. (2005). Promoting mental health - concepts, emerging evidence, practice: A report of the World Health Organization, Department of Mental Health and Substance Abuse in collaboration with the Victorian Health Promotion Foundation and the University of Melbourne. World Health Organization.

Hickey, J., Picciotto, A., Patel, W. \& Hunt, K. (2019). Promoting psychological health and early intervention in schools. I J. Faulconbridge, K. Hunt \& A. Laffan (red.), Improving the Psychological Wellbeing of Children and Young People - Effective Prevention and Early Intervention Across Health, Education and Social Care (s. 117-137). Jessica Kingsley Publishers.

Hogan, P. C. (2001). The Epilogue of Suffering: Heroism, Empathy, Ethics. SubStance, 30, 119-43.

Holtermann, S. \& Vedvik, K. O. (2020, 21. juli). Foreldre reagerer: - Elever har følt seg presset til å dele ting med klassen. Utdanningsnytt. https://www.utdanningsnytt.no/fagfornyelsen-livsmestring/foreldre-reagerer--elever-harfolt-seg-presset-til-a-dele-ting-med-klassen/234166

Jambak, T. (2021, 9. februar). Kunnskap, dannelse og læreplaner. Utdanningsnytt. https://www.utdanningsnytt.no/litteratur-skolepolitikk-thom-jambak/kunnskap-dannelse-oglaereplaner/272352 
Järvinen, M. \& Mik-Meyer, N. (red.) (2005). Kvalitative metoder i et interaksjonistisk perspektiv. Hans Reitzels Forlag.

Kaspersen, P. (2004). Tekstens transformationer. Doktoravhandling, Syddansk Universitet.

Keen, S. (2014). Narrative Empathy. I P. Hühn et al. (red.), Handbook of Narratology (s. 521-530). De Gruyter.

Kidd, D. C. \& Castano, E. (2013). Reading Literary Fiction Improves Theory of Mind. Science, 342(6156), 377-380. https://doi.org/10.1126/science.1239918

Kjelen, H. (2015). Litterær kompetanse - portrett av tre lesarar. Acta Didactica Norge, 9(1), Art. 12. https://doi.org/10.5617/adno.1390

Kunnskapsdepartementet (2017). Overordnet del - verdier og prinsipper for grunnopplæringen. Regjeringen. https://www.udir.no/lk20/overordnet-del/

Kunnskapsdepartementet (2019). Lcreplan i norsk (NOR01-06). Regjeringen. http://data.udir.no/kl06/v201906/laereplaner-lk20/NOR01-06.pdf

Kvale, S. (2007). Doing interviews. Sage Publications.

Lauritzen, L.-M. (2019a). En affektiv vending i norskfagets litteraturundervisning. Et grunnlag for folkehelse og livsmestring. Norsk litterær årbok. Samlaget.

Lauritzen, L.-M. (2019b). Bridging Disciplines: On Teaching Empathy Through Fiction. Tidsskrift for forskning i sygdom og samfund, 16(31), 127-140. https://doi.org/10.7146/tfss.v16i31.116960

Madsen, O. J. (2020). Livsmestring på timeplanen - rett medisin for elevene? Spartacus.

Mørch, W.-T. (2020, 30. september). Livsmestring i skolen er helt feil løsning. Nettavisen. https://www.nettavisen.no/nyheter/livsmestring-i-skolen-er-helt-feillosning/3424026078.html

NOU 2015: 8. Fremtidens skole - Fornyelse av fag og kompetanser. Kunnskapsdepartementet. https://www.regjeringen.no/no/dokumenter/nou-20158/id2417001/

Nussbaum, M. C. (1995). Poetic Justice: the literary imagination and public life. Beacon Press.

Nussbaum, M. C. (oversatt av I. Engelstad) (2016). Litteraturens etikk - følelser og forestillingsevne. Pax Forlag.

Oatley, K. (2016). Fiction: Simulation of Social Worlds. Trends in Cognitive Sciences, 20(8), 618-628. https://doi.org/10.1016/j.tics.2016.06.002

Olin-Scheller, C. (2006). Mellan Dante och Big Brother. Doktoravhandling, Karlstads Universitet.

Penne, S. (2001). Norsk som identitetsfag. Universitetsforlaget.

Ringereide, K. \& Thorkildsen, S. L. (2019). Folkehelse og livsmestring i skolen. Pedlex.

Rødnes, K. A. (2014). Skjønnlitteratur i klasserommet: Skandinavisk forskning og didaktiske implikasjoner. Acta Didactica Norge, 8(1), Art. 5. https://doi.org/10.5617/adno.1097

Sletten, M. A. \& Bakken, A. (2016). Psykiske helseplager blant ungdom - tidstrender og samfunssmessige forklaringer. Oslo Metropolitan University - OsloMet: NOVA.

Smidt, J. (1989). Seks lesere på skolen - hva de søkte, hva de fant: En studie av litteraturarbeid i den videregående skolen. Universitetsforlaget.

Stølen, T. (2017). Menneskets danning. I E. V. D. Haugen \& G. Stølen (red.), Pedagogisk mangfold - i et samfunnsperspektiv (s. 229-244). Universitetsforlaget.

Sælebakke, A. (2018). Livsmestring i skolen - et relasjonelt perspektiv. Gyldendal Akademisk.

Tollefsen, B. Y. (2020, 13. februar). Er folkehelse og livsmestring bare en privatsak? Fagsnakk. https://www.fagsnakk.no/skole-og-utdanning/er-folkehelse-og-livsmestringbare-en-privatsak/ 
Tveit, S. \& Olsen, R. V. (2018). Eksamens mange roller i sertifisering, styring og støtte av læring og undervisning i norsk grunnopplæring. Acta Didactica Norge, 12(4), Art. 18. https://doi.org/10.5617/adno.6381

Weare, K. \& Nind, M. (2011). Mental health promotion and problem prevention in schools: what does the evidence say? Health Promotion International, 26(issue suppl_1), i29-i69. https://doi.org/10.1093/heapro/dar075

Aase, L. (2005). Norskfaget - skolens fremste danningsfag? I K. Børhaug, A.-B. Fenner \& L. Aase (red.), Fagenes begrunnelser - skolens fag og arbeidsmåter i danningsperspektiv (s. 69-82). Fagbokforlaget. 